Investigating the source of radiocesium contaminated sediment in two Fukushima coastal catchments with sediment tracing techniques

Hugo Lepage $^{a^{*}}$, J. Patrick Laceby ${ }^{a}$, Philippe Bonté ${ }^{a}$, Jean-Louis Joron ${ }^{b}$, Yuichi Onda ${ }^{c}$, Irène Lefèvre $^{a}$, Sophie Ayrault ${ }^{a}$, Olivier Evrard ${ }^{a}$

${ }^{a}$ Laboratoire des Sciences du Climat et de l'Environnement (LSCE) - Unité Mixte de Recherche 8212 (CEA-CNRSUVSQ) - 91198 Gif-sur-Yvette, Cedex (France)

${ }^{b}$ IPGP 1 rue Jussieu, 75238 Paris cedex 05 and CEA/DSM/IRAMIS/NIMBE, Saclay, 91191 Gif-sur-Yvette

${ }^{c}$ Center for Research in Isotopes and Environmental Dynamics (CRIED), University of Tsukuba, 1-1-1 Tennodai,

Tsukuba, Ibaraki 305-8572, Japan

*Corresponding author email: Olivier.evrard@Isce.ipsl.fr 


\title{
Investigating the source of radiocesium contaminated sediment in two Fukushima coastal catchments with sediment tracing techniques
}

\begin{abstract}
The Fukushima Dai-ichi nuclear power plant accident resulted in the fallout of significant quantities of radiocesium. After deposition on the soil surface, rainfall and spring flood events transfer radiocesium downstream. Identifying the source of contaminated sediment is important for managing potential downstream radiocesium contamination.

Soil $(n=37)$ and sediment $(n=211)$ were sampled from November 2011 to May 2014 in the Mano and the Niida coastal catchments. Two sediment fingerprinting approaches quantified the source of radiocesium contaminated sediment. First, cesium-137 activities in surface soil and sediment samples were modelled to determine the contribution of upstream, more contaminated areas, to sediment transiting the more densely populated coastal plain. Second, elemental geochemistry of three major soil types (Andosols, Cambisols and Fluvisols) was used to model the relative contribution of these soils to sediment sampled throughout the catchments.

In the Niida catchment, $47 \%$ ( $\sigma 19 \%$ ) of sediment sampled in the coastal plain was modelled to be derived from the upstream area whereas, it was only $19 \%$ ( $\sigma$ 19\%) in the Mano catchment. The main factor driving this difference is the presence of a large dam on the main stem of the Mano River. Geochemical modelling results indicated that Fluvisols, an alluvial soil type on which paddy fields are typically cultivated, supply the majority of sediment $(\mu 76, \sigma 14 \%)$.

The results confirm that the management of dams is fundamental to radiocesium migration. Moreover, this research indicates that Fluvisols and concomitantly, rice paddies on this soil type, supply a disproportionate amount of sediment. Managing sediment derived from Fluvisols, while incorporating potential impacts from major dams, should help mitigate the downstream migration of radiocesium contaminated sediment.
\end{abstract}




\section{Introduction}

The Fukushima Dai-Ichi Nuclear Power Plant (FDNPP) accident on March 11, 2011 resulted in the deposition of vast quantities of radionuclides over Japanese soils (for a review see: Evrard et al., 2015). Among these radionuclides, cesium $-137\left({ }^{137} \mathrm{Cs}_{\mathrm{I}_{1 / 2}}=30.17 \mathrm{y}\right)$ will be the most serious health risk to the local population for the foreseeable future (Kitamura et al., 2014).

Cesium is rapidly and almost irreversibly fixated to fine soil particles, particularly clay minerals (Sawhney 1972; Kamei-ishikawa et al., 2008). Owing to this rapid fixation, ${ }^{137} \mathrm{Cs}$ is predominantly bound to fine particles in the top $0-5 \mathrm{~cm}$ of undisturbed soil profiles (Lepage et al., 2015). Importantly, these contaminated fine particles are preferentially eroded (Walling \& Woodward, 1992; Motha et al., 2002).

The Fukushima region has an erosive climate, particularly during the typhoon season (July October)(Laceby et al., in review). During typhoon events, significant volumes of contaminated sediment are transported downstream (Evrard et al., 2013; Lepage et al., 2014b). These major events result in elevated ${ }^{137} \mathrm{Cs}$ concentrations in suspended riverine material (Yoshikawa et al., 2014). For example, Typhoon Roke (September 2011) transferred 61\% (6 TBq) of the total radiocesium load in the Abukuma catchment between August 2011 to May 2012 (Yamashiki et al. 2014). Understanding the climatic influence on radiocesium and sediment fluxes is important.

Only the largest river draining the main radioactive pollution plume of the Fukushima Prefecture, the Abukuma River, has been continuously monitored since the accident (Chartin et al., 2013). Alternative sample-based approaches are therefore required to examine sources of ${ }^{137} \mathrm{Cs}$ contaminated sediment in the other coastal rivers (Chartin et al., 2013; Lepage et al., 2014a). In lieu of monitoring, sediment fingerprinting techniques provide a direct method to identify and quantify sediment contributions from different areas through analyzing and modelling source soil and sediment properties (Collins and Walling, 2002; Haddadchi et al., 2013).

In this post-accident context, sediment source contributions are quantified with two sediment fingerprinting techniques. First, $a{ }^{137} \mathrm{Cs}$-based approach is used to investigate the downstream migration of ${ }^{137} \mathrm{Cs}$-contaminated sediment. Here, ${ }^{137} \mathrm{Cs}$ activities are quantified in two distinct catchment areas: the upstream, highly contaminated region and the coastal plains that received low levels of ${ }^{137} \mathrm{Cs}$ fallout. The objective of this ${ }^{137} \mathrm{Cs}$-based fingerprinting is to examine the source of ${ }^{137} \mathrm{Cs}$-contaminated sediment transiting the more densely populated coastal plain.

Second, elemental geochemistry of sediment and three main soil types (Andosols, Cambisols and Fluvisols) is analysed to determine the relative contribution of these soils to ${ }^{137} \mathrm{Cs}$-contaminated sediment. Conservative elements are selected for modelling with the Kruskal Wallis H-test and Discriminant Function Analysis (Collins et al., 1997; Wilkinson et al., 2013). Distribution models are used to identify sediment sources for both fingerprinting approaches (Laceby and Olley, 2015).

For most of the Fukushima-impacted catchments, the downstream, more densely populated coastal plains were less-affected by the initial fallout. Therefore, it is important to understand the sources of contaminated sediment transiting these coastal plains. This application of sediment fingerprinting techniques improves our knowledge of the sources of ${ }^{137} \mathrm{Cs}$-contaminated sediment transiting these coastal plains. This improved understanding will assist the long-term management of radioactive contamination in the Fukushima Prefecture. 


\section{Materials and methods}

\subsection{Study site description}

This research was conducted in the Mano $\left(175 \mathrm{~km}^{2}\right)$ and Niida $\left(275 \mathrm{~km}^{2}\right)$ catchments (Fig. 1). The main features of these catchments include an upstream coastal mountain range $(<900 \mathrm{~m})$ and a broad, more densely inhabited, coastal plain (Geospatial Information Authority of Japan, 2015). Soils in the upstream areas of these catchments were heavily contaminated, with soil radiocesium $\left({ }^{134} \mathrm{Cs}+\right.$ ${ }^{137} \mathrm{Cs}$ ) inventories ranging from $20 \mathrm{kBq} \mathrm{kg}^{-1}$ to $150 \mathrm{kBq} \mathrm{kg}^{-1}$ (Fig. 1) (Chartin et al., 2013). In contrast, soil radiocesium inventories in the lowland coastal plains were less than $20 \mathrm{kBq} \mathrm{kg}^{-1}$.

An important hydrological distinction between these catchments is the presence of a major dam on the main stem of the Mano River. The only major dam in the Niida River catchment is situated on a tributary (Fig. 1). Catchment land use mainly consists of forest (72\%) and cropland (12\%) (Land Conservation Research, 2005). Paddy fields constitute the majority of the cropland agriculture, typically cultivated on alluvial soils. Cambisols comprise $59 \%$ of the soil types for these two catchments, followed by Andosols (22\%) and Fluvisols (7\%) (Economic Planning Agency 1972). Cambisols and Andosols are predominantly located in the upper catchment, whereas the Fluvisols are mainly located near the river channel in upstream reaches and are ubiquitous throughout the coastal plain (Fig. 4).

\subsection{Soil and sediment sampling}

Six sampling campaigns were conducted between November 2011 and May 2014. Sediment sampling occurred bi-annually: in November after the typhoon season, and in spring, after the snowmelt runoff (Fig. 2). The goal was to sample deposited sediment that was transferred during these main erosive periods. Cumulative rainfall reached $3300 \mathrm{~mm}$ at a gauging station in the Niida catchment monitored between March 2011 and May 2014. This monitoring period included three typhoons and one tropical storm. Mean annual rainfall in the Fukushima region is $1387 \mathrm{~mm}$ (Laceby et al., in review).

Fine sediment samples $(n=211)$ were taken from material deposited after the last major event at the same sites, during each of the six campaigns (Fig. 3 and Fig. 4). These lag deposit samples are comprised of fine particulate material that settled during the falling limb of the last significant hydrosedimentary event.Lag deposit samples have proven to be comparable to in-situ suspended sediment samples in sediment fingerprinting research (Olley et al., 2013a). Ten subsamples ( $\sim 5 \mathrm{~g}$ per subsample) of recent lag deposit material were taken with a plastic spatula over a $5 \mathrm{~m}$ reach down to the underlying coarser cobble or gravel layer and composited into one sample. Lag deposit samples are referred to as sediment for the remainder of the text.

To investigate the source of ${ }^{137} \mathrm{Cs}$-contaminated sediment transiting the coastal plain, the catchments were subdivided into their two inherent, dominant features (the upstream mountainous area and the coastal plain). The fallout from the contamination plume exhibits a somewhat similar upland/lowland pattern, with a radiocesium threshold inventory of $20 \mathrm{kBq} \mathrm{kg}^{-1}$ delineating these two distinct catchment features (Fig. 3). An elevation threshold of $\sim 100 \mathrm{~m}$ provides a similar spatial delineation between these upland/lowland features (Fig. 1). As the goal is to trace the movement of ${ }^{137} \mathrm{Cs}$-contaminated sediment, the threshold of $20 \mathrm{kBq} \mathrm{kg}^{-1}$ of radiocesium is used to delineate these two sources.

Two approaches were used to develop a ${ }^{137} \mathrm{Cs}$ source dataset for modelling. First, soil samples $(n=37)$ were collected in locations reported by Chartin et al., (2013) to be highly connected to the stream 
network. At each of these locations, ten subsamples ( $\sim \mathrm{g}$ per subsample) were scraped from the soil surface randomly in a $10 \mathrm{~m}^{2}$ quadrant using a non-metallic trowel and composited into one sample. Second, ${ }^{137} \mathrm{Cs}$ activities were included for 99 soil samples collected in the upper 5 centimetres of the soils in June and July 2011 in these two catchments by the Japanese Ministry of Education, Culture, Sports, Science and Technology (MEXT, 2011)(Fig. 3). Their ${ }^{137} \mathrm{Cs}$ activities remained in the same range as those measured in soil samples collected for this study.

To determine the relative contribution of the different soil types to ${ }^{137} \mathrm{Cs}$-contaminated sediment, the highly connected soil samples from soil types that covered $>5 \%$ of the catchment area were selected for elemental analyses. This $5 \%$ threshold excludes areas downstream from the lowest sediment sampling point as these soils do not contribute to sediment sampled. In addition, three soil samples were collected in the Ota catchment, south of the Niida catchment (Fig. 4). In total, 15 soil samples were analysed from Andosols, 12 from Cambisols and 7 from Gleyic Fluvisols (Fig. 4). Gleyic Fluvisol are here after referred to as Fluvisols.

\subsection{Laboratory analyses}

\subsubsection{Gamma spectrometry}

All samples were dried at $40^{\circ} \mathrm{C}$ for $\sim 48 \mathrm{~h}$ and sieved to $2 \mathrm{~mm}$, as previous studies conducted in Fukushima region showed that ${ }^{137} \mathrm{CS}$ is attached to multiple particle size fractions, including the coarser (> 63 $\mu \mathrm{m}$ ) grain fractions (see Evrard et al., 2015, and references therein). Samples were then ground to a fine powder in an agate mortar, and pressed into $15 \mathrm{~mL}$ polyethylene containers for measurement. ${ }^{137} \mathrm{Cs}$ activities were determined with gamma spectrometry using coaxial $\mathrm{N}$ - and Ptype HPGe detectors (Canberra/Ortec). ${ }^{137} \mathrm{Cs}$ activities were measured at the $661 \mathrm{keV}$ emission peak. Counting times for samples varied between $80,000 \mathrm{~s}$ and $150,000 \mathrm{~s}$.

Counting efficiencies and energy calibration were monitored using internal, national and certified International Atomic Energy Agency (IAEA) reference materials prepared in the same containers as the samples. Uncertainties were calculated by combining counting statistics and calibration uncertainties. Summing and self-absorption ffects were taken into-account by analysing standards with similar densities and characteristics as the collected samples. All activities were decay-corrected to March 14, 2011, the date of the main radionuclide fallout deposition (Kinoshita et al., 2011; Shozugawa et al., 2012).

\subsubsection{Instrumental neutron activation analysis}

Given the difficulties to find laboratories willing to analyze radiocesium contaminated-sediment with mass-spectrometry, elemental concentrations were measured with instrumental neutron activation analysis (INAA) (Joron et al., 1997). This approach has already been used in sediment fingerprinting studies to characterize elemental concentrations in soils and sediments (Evrard et al., 2011).

Approximately $50 \mathrm{mg}$ of dried soil and sediment was sealed in individual polyethylene bags and packed in aluminium containers. Due to schedule constraints, irradiation was performed in two different reactors.

First, 8 aluminium containers, each containing approximately 18 samples, with two certified reference materials (CRM) were irradiated for 30 min with a thermal neutron flux of $2.3^{*} 10^{13} \mathrm{n} \mathrm{cm}^{-2}$ $\mathrm{s}^{-1}$. These irradiations were performed in the experimental reactor Orphée at the French Alternative Energies and Atomic Energy Commission (CEA, Saclay, France). After a 4 day decay period, the individual polyethylene sample bags were measured 4 times with gamma spectrometry (counting time: $600-36,000$ s) (Tessier \& Bonté, 2002). 
Second, in the experimental reactor Osiris at the CEA (Saclay, France), 8 cadmium containers were irradiated for $8 \mathrm{~h}$ with a neutron flux of $2 * 10^{14} \mathrm{n} \mathrm{cm}^{-2} \mathrm{~s}^{-1}$. Seven CRM were placed in these containers. Samples were first measured by gamma spectrometry 7 days after the irradiation (counting time: $\sim 3000 \mathrm{~s}$ ) and again, one month after the irradiation (counting time: 20,000-40,000 s). Additional information on this method can be found in Joron et al. (1997).

To incorporate samples from both irradiation methods, the results obtained for soil and sediment samples $(n=66)$ that were irradiated with both methods, were compared. Elemental concentrations that differed in this comparison by an average greater than $15 \%$ were removed from further analyses. In total, twelve elements were retained for analysis and modelling ( $\mathrm{Ce}, \mathrm{Co}, \mathrm{Cs}, \mathrm{Fe}, \mathrm{Hf}$, La, $\mathrm{Na}, \mathrm{Sc}, \mathrm{Sm}, \mathrm{Th}, \mathrm{Yb}, \mathrm{Zn})$.

\subsection{Distribution modelling}

Two distinct modelling approaches were employed. The first approach modelled ${ }^{137} \mathrm{Cs}$ activities to quantify sediment contributions from two sources: the upstream area and the coastal plain. The second approach modelled three sources: Andosols, Cambisols and Fluvisols. Both approaches incorporated a distribution modelling framework (Laceby and Olley, 2015). Modelling distributions throughout the entire modelling framework, including sediment, source, and proportional contribution distributions, reduces model uncertainty (Olley et al., 2013b).

\subsubsection{The two-source model}

To model distributions for in-stream sediment samples, the lag-deposit samples were first grouped by catchment and then by sampling campaign. As the radiocesium inventories differed in the two catchments, source sample distributions were derived for the upstream and coastal plain areas for each respective catchment. To address the high range of standard deviation in upstream areas $\left({ }^{137} \mathrm{Cs}\right.$ activity ranging from 2 to $78 \mathrm{kBq} \mathrm{kg}^{-1}$ in soil samples), the median and the median absolute deviation (MAD) were used to model source distributions. These median-based source distributions were modelled to quantify the contribution of upstream sediment to sediment transiting the coastal plain, with:

$A x+B(1-x)=C$

Eq. 1

where $A$ and $B$ are the median-based source distributions (i.e. the upstream and coastal plain areas), $x$ is the contribution of the source $A$, and $C$ is the median-based distribution of the sediment group modelled. In this modelling framework, $x$ is modelled as a truncated normal distribution $(0 \leq x \leq 1)$ with a mixture mean $\left(\mu_{m}\right)$ and standard deviation $\left(\sigma_{m}\right)$ following Caitcheon et al. (2012) and Olley et al. (2013a). The model was optimized with the Optquest algorithm in Oracle's Crystal Ball software (2013) as described after the three-source model.

\subsubsection{The three-source model}

The optimal elemental suite to discriminate between the soil sources was selected with a three step process. First, conservative behaviour of the elements was examined with a distribution basedapproach. Elements were considered to be conservative when the mean of every individual sediment grouping plotted within the distribution source range. The distribution source range boundary was determined as the range between the maximum source mean plus one standard deviation and the minimum source mean minus one standard deviation. This conservativeness test ensures that all sediment grouping means plot within one standard deviation of the source means.

Second, the Kruskal Wallis rank sum test removed elements that did not provide significant source discrimination (i.e. $p>0.05$ )(Collins et al., 1997). Third, a discriminant function analysis (DFA) selected 
the elements that provide an optimal source discrimination (Collins and Walling, 2002). These statistical tests were performed using R software (version 3.0.0) and the library Rcmdr (version 2.0$3)$.

A distribution mixing model then quantified the contribution of each source to the sediment sample groupings through minimizing the mixing model difference (MMD)(Laceby and Olley, 2015):

$M M D=\sum_{i=1}^{n}\left|\left(C_{i}-\left(\sum_{S=1}^{m} P_{S} S_{S i}\right)\right) / C_{i}\right|$

where $n$ is the number of elements in the model; $C_{i}$ is the sediment group normal distribution of element property (i); $m$ is the number of sources in the catchment; $P_{s}$ is the source $(s)$ contribution mixture distribution; $S_{s i}$ is the normal distribution of element (i) in source $(s)$. Similarly to Eq. $1, P_{s}$ is is modelled as a truncated normal distribution $(0 \leq x \leq 1)$ with a mixture mean $\left(\mu_{m}\right)$ and standard deviation $\left(\sigma_{m}\right)$. Correlations between elemental concentrations in each source were incorporated into the mixing model to maintain elemental relationships existing within each source (Laceby \& Olley, 2015; Cooper et al., 2015).

\subsubsection{Modelling parameterization}

The Optquest algorithm in Oracle's Crystal Ball software (2013) solved Eq. 1 and 2 within a Monte Carlo style framework. Eq. 1 was solved by minimizing the median difference when subtracting the distributions of both sides of this equation. Eq. 2 was solved by minimizing the median of MMD. Nonnegative constraints were modelled for all source and sediment distributions, and correlations are incorporated directly into the Optquest algorithm. The Optquest algorithm functions similarly to the solver function in Microsoft Excel, with the expanded capability of incorporating Latin Hypercube sampling, correlations, and distributions throughout the entire modelling framework into a Microsoft Excel based modelling environment. For more details, see Laceby and Olley (2015), or Foucher et al., (2015).

The optimal source contribution $\left(x\right.$ or $P_{s}$ ) was determined by the solving of these equations with the Optquest algorithm. For an individual simulation, 2500 Latin Hypercube (500 bins) samples were drawn from the source and sediment distributions while solving the equations by varying the mixture mean $\left(\mu_{m}\right)$ and standard deviation $\left(\sigma_{m}\right)$. This model simulation and solving process was then repeated 2500 times with the median proportional source contribution from these 2500 additional simulations, reported as the contribution of each source.

For each source, model uncertainty (MU) was determined by summing (1) the MAD of the individual source median contribution for the additional 2500 simulations, (2) the modelled standard deviation, and (3) the MAD of this modelled standard deviation for the 2500 model simulations (Laceby et al., 2015).

\section{Results}

\subsection{Downstream migration of radiocesium contaminated soil}

Soils in the upstream areas of these catchments were highly contaminated and characterized with a wide range of ${ }^{137} \mathrm{Cs}$ activities (Niida: $\mu 28, \sigma 16 \mathrm{kBq} \mathrm{kg}^{-1}$, Mano: $\mu 18, \sigma 13 \mathrm{kBq} \mathrm{kg}^{-1}$ ) (Table 1). In both catchments, the coefficients of variation for source ${ }^{137} \mathrm{Cs}$ activities were greater than $50 \%$. This 
resulted in poor preliminary model performance with normal distributions. In the Mano River, the upstream area (Table 1). In the Niida catchment, median ${ }^{137} \mathrm{Cs}$ activities were $3.7 \mathrm{kBq} \mathrm{kg}^{-1}$ (MAD 2.2 ) in the coastal plain, compared to $27.3 \mathrm{kBq} \mathrm{kg}^{-1}$ (MAD 9.7) in the upstream area.

The relative MAD was lower than the coefficient of variation for each source, with this difference being most pronounced for the upstream source areas (Table 1). Narrowing the distribution widths by modelling median-MAD derived distributions (Fig. 5) is hypothesized to have improved model performance, evident through visibly and statistically improved fit between mixture and in-stream sediment distributions.

The mean contribution of upstream soils to sediment transiting the coastal plain was $34 \%$ ( $\sigma 24 \%)$ for both catchments. The mean upstream contribution for the Niida catchment was more than double $(\mu$ 47, $\sigma 19 \%)$ the contribution in the Mano catchment ( $\mu$ 19, $\sigma$ 19\%) (Fig. 6). For the Niida catchment, the highest upstream contribution was $71 \pm 11 \%$ in April 2012 (Table 2). This contribution decreased to $22 \pm 13 \%$ in May 2013, before increasing again in November 2013 (66 $\pm 10 \%$ ). During the last campaign (May 2014), the contribution of the upstream area decreased to $32 \pm 15 \%$.

The temporal results in the Mano catchment varied similarly. The highest contribution was again modelled in April 2012 (50 $\pm 11 \%)$, with an increase between May 2013 (13 $\pm 12 \%)$ and November 2013 (24 \pm 12\%). In May 2014, sediment in the Mano catchment coastal plain was modelled to be derived exclusively from coastal plain soils, with negligible upstream contributions $(0 \pm 15 \%)$.

\subsection{Source of radiocesium-contaminated soils}

Two elements ( $\mathrm{Na}$ and $\mathrm{Zn}$ ) were not conservative and were accordingly removed from further analysis. Three elements were selected with the Kruskal Wallis $\mathrm{H}$-test that provided significant discrimination between the soil sources (Table 3). From these elements, the DFA selected scandium (Sc) and ytterbium (Yb) as the optimal elemental suite for modelling source contributions from Andosols, Cambisols and Fluvisols (Table 3). The source discrimination provided by $\mathrm{Sc}$ and $\mathrm{Yb}$ is plotted in Fig. 7. Sc and $\mathrm{Yb}$ had a strong positive correlation in Cambisols (0.510), a negative correlation in Fluvisols (-0.348), and minimal correlation in Andosols (0.121).

Modelling results (Table 4, Fig. 8) indicate that Fluvisols are the dominant source supplying sediment in both catchments with a mean contribution of $76 \%$ ( $\sigma$ 14\%). Andosols were the second largest sediment source ( $\mu 21, \sigma 16 \%)$, followed by Cambisols ( $\mu 3, \sigma 4 \%)$. In the Niida catchment, the mean Fluvisol contribution was $70 \%$ ( $\sigma 10 \%$ ), followed again by Andosols $28 \%$ ( $\sigma 11 \%$ ) and Cambisols $2 \%$ ( $\sigma$ $3 \%)$. Fluvisol sediment contributions were higher in the Niida catchment coastal plain $(\mu 75, \sigma 7 \%)$ compared to the upstream area ( $\mu 66, \sigma 11 \%)$. Contrarily, Andosol contributions increased from a mean $21 \%(\sigma 6 \%)$ in the coastal plain to $33 \%$ ( $\sigma 13 \%$ ) in the upstream areas. Overall, Cambisol contributions were negligible $(\mu<5 \%)$.

There were no seasonal trends for soil sources in the Niida catchment with the largest differences between snowmelt and post typhoon soil contributions differing by a maximum of only $3.5 \%$. The highest Fluvisol contribution was $83 \pm 10 \%$ in November 2013 for the coastal plain, compared to the lowest contribution of $60 \pm 10 \%$ in the upstream area in November 2011. Although there were differences in soil source contributions over time, in general, the main result is the dominance of Fluvisols as the main sediment source in the Niida catchment.

In the Mano Catchment, modelling results again indicate that Fluvisols are the dominant source of

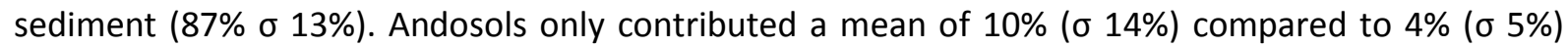


from Cambisols. There was a difference of $<5 \%$ between Fluvisol sediment contributions from the Mano catchment coastal plain ( $\mu 89 \% \sigma 1 \%)$ and the upstream area $(\mu 85 \% \sigma 16 \%)$. There was a switch between secondary contributions with Cambisols contributing a mean of $10 \%$ ( $\sigma 1 \%$ ) for the coastal plains compared to $1 \%(\sigma 1 \%)$ in the upstream areas. Andosols conversely contributed a mean of $1 \%(\sigma 1 \%)$ in the coastal plain and $14 \%$ in the upstream area ( $\sigma 1 \%)$.

In the Mano catchment, Fluvisols contributed more than $88 \%$ of sediment for six of the sediment groupings modelled. The only two Fluvisol contributions below $88 \%$ were the November 2012 and May 2013 sampling campaigns where the contributions dropped to $70 \%$. For these sampling campaigns periods, Andosols had their highest source contributions ( $30 \%)$. The remainder of sediment sampled in the Mano catchment was almost entirely derived from Fluvisols (>87\%).

\section{Discussion}

\subsection{Radiocesium-contaminated sediment transfers}

One common approach to trace sediment sources with ${ }^{137} \mathrm{Cs}$ is to investigate whether sediment are derived from surface or subsoil sources (Olley \& Murray., 1993; Gourdin et al., 2014). In the Fukushima region, this approach is inapplicable owing to the heterogeneous deposition of ${ }^{137} \mathrm{Cs}$. Although heterogeneous, the ${ }^{137} \mathrm{Cs}$ deposition effectively established two distinct spatial units in the Mano and Niida catchments: the coastal plain and upstream areas. These spatial units have conceptually similar ${ }^{137} \mathrm{Cs}$ distributions as surface soils (elevated ${ }^{137} \mathrm{Cs}$ activities-upstream) and subsoils (low ${ }^{137} \mathrm{Cs}$ activities-coastal)(Fig. 5). Although modelling source and sediment ${ }^{137} \mathrm{Cs}$ activities in the Fukushima Prefecture does not allow for an examination of erosion processes, it allows for an insightful investigation into the downstream dispersion of radiocesium-contaminated soils in these particular catchments.

Approximately $34 \%$ ( $\sigma 24 \%$ ) of sampled sediment transiting the coastal plains for both catchments was modelled to be derived from the upper catchment areas. In the Niida catchment, almost half of the sediment ( $\mu 47, \sigma 19 \%)$ was modelled to be derived from the upstream areas compared to approximately one fifth in the Mano catchment ( $\mu$ 19, $\sigma 19 \%$ ) (Fig. 6). These results support the research of Chartin et al. (2013) who traced a downstream migration of radiocesium-contaminated sediment through the coastal plains in the Niida catchment.

Although there was a substantial dispersion of radiocesium contaminated sediment downstream, these transfers differed in both catchments. The presence of a major dam on the main tributary of the Mano River likely resulted in the $28 \%$ lower downstream dispersion of radiocesium contaminated sediment from the upstream area. This confirms the influence of major dams on radiocesium migration and dispersion in the Fukushima region (Kitamura et al., 2014).

There were seasonal patterns of downstream radiocesium dispersion confirming a direct linkage between radiocesium contaminated sediment transfers and the region's climate (Evrard et al., 2014a). The increase of upstream contributions in both catchments in November 2013 is attributed to typhoons that occurred in September and October 2013. During this period, there was a modelled increase in the upstream contribution in the Niida catchment of $44 \%$ compared to the previous sampling campaign (May 2013). In the Mano catchment, the increase was only $11 \%$, again indicative of the influence of the Mano Dam on downstream radiocesium-contaminated sediment transfers. These observed temporal variations may be attributed to the intensity of the erosive events. Several studies conducted in the Fukushima Prefecture demonstrated that most of the contamination was transported by the rivers during typhoons (Yamaguchi et al., 2014; Yamashiki et al., 2014). 
Decreases in the sediment contributions modelled from the upstream area in the Niida catchment from April 2012 to May 2013 may be indicative of ongoing decontamination works that commenced in 2012. To reduce contamination, there has been a massive remediation effort in the Niida catchment since the 2012 summer with vegetation and the uppermost soil layer $(\sim 5 \mathrm{~cm})$ removed from cultivated soils (Yasutaka \& Naito, 2015). It has been demonstrated that decontamination may potentially increase the dose rates measured in river sediment (Evrard et al., 2014b; Lepage et al., 2014a). Therefore, the increased contribution of the upstream soils to the coastal plain sediments could be related to the occurrence of these decontamination works. Indeed, the application of this modified ${ }^{137}$ Cs-tracing technique could monitor the impact of decontamination works in the Fukushima region.

\subsection{Radiocesium-contaminated sediment sources}

Fluvisols were found to be the main soil type supplying sediment in both catchments ( $\mu 73, \sigma 30 \%)$. This soil type is mainly found in paddy fields (National Institute for Agro-Environmental Sciences (NIAES), 1996; Food and Agriculture Organization, 2014). In the literature, sediment tracing and fingerprinting research also indicates that channel banks, potentially located on Fluvisols or other alluvial material may also be a dominant sediment source (Olley et al., 2013a). A significant proportion of channel banks in the Mano and Niida catchments are channelized and effectively demobilized with cement. Although there may be remobilization of materials temporarily stored within these extensive, anthropogenically modified channel networks, it is unlikely that channel bank subsoil material was a measurable sediment source during this sampling period.

Accordingly, Fluvisols, and indirectly rice paddy fields cultivated on Fluvisols, are the main source of sediment in the Mano and Niida catchments. Chartin et al. (2013) also indicated that rice paddy fields are likely to be a major sediment source owing to their high connectivity to the river channel. Managing radiocesium contamination of rice paddy fields cultivated on Fluvisols is extremely important as approximately $70 \%$ of the agriculture in the Fukushima Prefecture is rice-oriented (Wakahara et al., 2014). Therefore, effective management of paddy field contamination and also potential future downstream sediment-bound radiocesium transfers, both to and from paddy fields, will be fundamental for the economy and the general health of the local population.

Andosols, which contribute approximately a fifth of the sediment $(\mu 21 \%, \sigma 26 \%)$ to rivers in both catchments, may also occur in some paddy fields (Matsuzaka, 1977; NIAES, 1996). The $20 \%$ higher contribution of Andosols in the Niida compared to the Mano catchment is likely the result of thicker volcanic ash deposits in the Niida catchment (Yamamoto, 2013). In particular, it may be important to investigate any specific Andosol contributions in isolated regions of these catchments with high radiocesium activities.

Cambisols were only modelled to contribute a mean of $6 \%$ ( $\sigma$ 14\%) of sediment for both catchments even though they occupy 59\% of the catchment surface area. As Cambisols predominantly underlie forests, this confirms the low erodibility of forest soils in the region (Yoshimura et al., 2015). Approximately $66 \%$ of terrestrial fallout was deposited on forests (Hashimoto et al., 2012). As forest erosion rates are low (Yoshimura et al., 2015), the odds of this radiocesium contaminated sediment being mobilized from forests are likely similarly low. Conversely, there may be massive episodic typhoons in this region that could result in erosion and export of radiocesium-contaminated material from Cambisols.

\subsection{Management and research implications}


The customization of ${ }^{137} \mathrm{Cs}$ tracing-techniques to examine the downstream dispersion of radiocesiumcontaminated sediment could be an effective approach for the long-term monitoring of radiocesium migration. Moreover, this approach could be an important method for investigating the impacts of decontamination across the region. In particular, the examination of sediment cores from dams or reservoirs, or even floodplains along with sediment from automated sampling stations or timeintegrated samplers may provide a more comprehensive understanding of radiocesium dispersion. The approach could be applied over a range of scales throughout the region. Ultimately, this technique holds promise to provide more insight into radiocesium transfer dynamics and fluxes in the Fukushima region along with other fallout impacted regions in the future.

The application of geochemical fingerprinting techniques in the Fukushima region clearly indicated that Fluvisols are a dominant source of sediment. This application, owing to the recent age of soils and the dominance of volcanic activity, demonstrated a unique approach to geochemical fingerprinting focused on soil types rather than geology. There were two main challenges with the application of this technique. First, there may simply be an influence of geology or varying subtypes of soil classes that may impact the fingerprinting results. Second, it was difficult to find laboratories willing to analyze radiocesium contaminated-sediment with mass-spectrometry. The result of these challenges was a narrow suite of elements provided with INAA, leading to only three elements providing significant discrimination between these soil types.

Ultimately, these geochemical fingerprinting results are preliminary. More research needs to be undertaken in the region to confirm the dominance of Fluvisols with a broader suite of source samples and elements capable of source soil discrimination. Further, other sediment properties should be analyzed to examine whether sediments are derived from rice paddies or other major land uses in the region. These other sediment properties could potentially trace erosion processes similarly to ${ }^{137} \mathrm{Cs}$ and be analyzed in sediment cores and through other in-stream sampling methods. Such an approach would comprehensively characterize the soils dominating the supply of radiocesium-contaminated sediment in the region.

\section{Conclusions}

After the FDNPP accident, the downstream migration of radiocesium contaminated sediment was investigated for the Mano and Niida catchments. In the Niida catchment, upstream, contaminated sediment contributions were double ( $\mu$ 47, $\sigma 19 \%)$ what was transferred downstream in the Mano catchment ( $\mu$ 19, $\sigma 19 \%)$. The Mano Dam likely results in these catchment differences. Further, erosive typhoons in 2013 led to elevated downstream dispersion of radiocesium-contaminated sediment in both catchments, confirming the strong impact of climate on radiocesium transfers in the Fukushima Prefecture.

Fluvisols were modelled to be the dominant soil source of radiocesium contaminated sediment. As paddy fields often are cultivated in Fluvisols and channel banks are not a major sediment source, it is likely that paddy fields are a major source of sediment in the Fukushima region. Installing long term monitoring networks will be important to investigate the impact of the decontamination works and the related reduction of contamination dispersion from paddy fields. In this post-accident context, where soils in the upstream area of these catchments are heavily contaminated, understanding the sources and downstream dispersion of contaminated particles is paramount to the long-term management of radiocesium contamination. 


\section{References}

Caitcheon, G.G., Olley, J.M., Pantus, F., Hancock, G., Leslie, C., 2012. The dominant erosion processes supplying fine sediment to three major rivers in tropical Australia, the Daly (NT), Mitchell (Qld) and Flinders (QId) Rivers. Geomorphology 151-152, 188-195.

Chartin, C., Evrard, O., Onda, Y., Patin, J., Lefèvre, I., Ottlé, C., Ayrault, S., Lepage, H., Bonté, P., 2013. Tracking the early dispersion of contaminated sediment along rivers draining the Fukushima radioactive pollution plume. Anthropocene 1, 23-34.

Collins, a. L., Walling, D.E., Leeks, G.J.L., 1997. Source type ascription for fluvial suspended sediment based on a quantitative composite fingerprinting technique. Catena 29, 1-27.

Collins, A., Walling, D., 2002. Selecting fingerprint properties for discriminating potential suspended sediment sources in river basins. J. Hydrol. 261, 218-244.

Cooper, R. J., Krueger, T., Hiscock, K. M., \& Rawlins, B. G., 2014. Sensitivity of fluvial sediment source apportionment to mixing model assumptions: A Bayesian model comparison. Water Resources Research, 50, 9031-9047.

Economic Planning Agency, 1972. Scale 1:200,000 Fundamental Land Classification Survey in Fukushima (soil map). www.mlit.go.jp/kokjo/inspect/landclassification/download/index.html (Last access May 2015)

Evrard, O., Navratil, O., Ayrault, S., Ahmadi, M., Némery, J., Legout, C., Lefèvre, I., Poirel, A., Bonté, P., Esteves, M., 2011. Combining suspended sediment monitoring and fingerprinting to determine the spatial origin of fine sediment in a mountainous river catchment. Earth Surf. Process. Landforms 36, 1072-1089.

Evrard, O., Chartin, C., Onda, Y., Patin, J., Lepage, H., Lefèvre, I., Ayrault, S., Ottlé, C., Bonté, P., 2013. Evolution of radioactive dose rates in fresh sediment deposits along coastal rivers draining Fukushima contamination plume. Sci. Rep. 3.

Evrard, O., Chartin, C., Onda, Y., Lepage, H., Cerdan, O., Lefèvre, I., Ayrault, S., 2014a. Renewed soil erosion and remobilisation of radioactive sediment in Fukushima coastal rivers after the 2013 typhoons. Sci. Rep. 4.

Evrard, O., Pointurier, F., Onda, Y., Chartin, C., Hubert, A., Lepage, H., Pottin, A.-C., Lefèvre, I., Bonté, P., Laceby, J.P., Ayrault, S., 2014b. Novel Insights into Fukushima Nuclear Accident from Isotopic Evidence of Plutonium Spread along Coastal Rivers. Environ. Sci. Technol. 48, 9334-9340.

Evrard, O., Laceby, J.P., Lepage, H., Onda, Y., Cerdan, O., Ayrault, S., 2015. Radiocesium transfer from hillslopes to the Pacific Ocean after the Fukushima Nuclear Power Plant accident: A review. J. Environ. Radioact. 148, 92-110.

Food and Agriculture Organisation, 2014. World Reference Base for Soil Resources 2014, International soil classification system for naming soils and creating legends for soil maps. World Soil Resources Reports No. 106.

Foucher, A., Laceby, J.P., Salvador-Blanes, S., Evrard, O., Le Gall, M., Lefèvre, I., Cerdan, O., Rajkumar, V., Desmet, M., 2015. Quantifying the dominant sources of sediment in a drained lowland agricultural catchment: novel insights provided through sediment fingerprinting with ${ }^{137} \mathrm{Cs}$ and thorium-based particle size corrections. Geomorphology. 
Geospatial Information Authority of Japan, Japanese Ministry of Land, Infrastructure, Transport and Tourism. Digital Elevation Model, http://www.gsi.go.jp (Last access May 2015)

Gourdin, E., Evrard, O., Huon, S., Lefèvre, I., Ribolzi, O., Reyss, J., Sengtaheuanghoung, O., Ayrault, S., 2014. Suspended sediment dynamics in a Southeast Asian mountainous catchment : Combining river monitoring and fallout radionuclide tracers. J. Hydrol. 519, 1811-1823.

Haddadchi, A., Ryder, D.S., Evrard, O., Olley, J., 2013. Sediment fingerprinting in fluvial systems: review of tracers, sediment sources and mixing models. Int. J. Sediment Res. 28, 560-578.

Hashimoto, S., Ugawa, S., Nanko, K., Shichi, K., 2012. The total amounts of radioactively contaminated materials in forests in Fukushima, Japan. Sci. Rep. 2.

Japanese Meteorological Agency, Rainfall information. http://www.data.jma.go.jp/obd/stats/etrn, (Last access May 2015) (in Japanese)

Joron, J.L., Treuil, M., Raimbault, L., 1997. Activation analysis as a geochemical tool: Statement of its capabilities for geochemical trace element studies. J. Radioanal. Nucl. Chem. 216, 229-235.

Kamei-Ishikawa, N., Uchida, S., Tagami, K., 2008. Distribution coefficients for ${ }^{85} \mathrm{Sr}$ and ${ }^{137} \mathrm{CS}$ in Japanese agricultural soils and their correlations with soil properties. J. Radioanal. Nucl. Chem. 277, 433-439.

Kinoshita, N., Sueki, K., Sasa, K., Kitagawa, J., Ikarashi, S., Nishimura, T., Wong, Y.-S., Satou, Y., Handa, K., Takahashi, T., Sato, M., Yamagata, T., 2011. Assessment of individual radionuclide distributions from the Fukushima nuclear accident covering central-east Japan. Proc. Natl. Acad. Sci. U. S. A. 108, 19526-19539.

Kitamura, A., Yamaguchi, M., Kurikami, H., Yui, M., Onishi, Y., 2014. Predicting sediment and cesium137 discharge from catchments in eastern Fukushima. Anthropocene 5, 22-31.

Laceby, J.P., Mc McMahon, J., Evrard, O., Olley, J.M., 2015. Comparison of geological and statistical approaches to element selection for sediment fingerprinting. J. Soils Sediments 15, 2117-2131.

Laceby, J.P., Olley, J., 2015. A new modelling approach to tracing sediment sources that incorporates distributions and their elemental correlations. Hydrol. Process. 29, 1669-1685.

Laceby, J.P., Chartin, C., Evrard, O., Onda, Y., Garcia-Sanchez, L., Cerdan, O., In review. Rainfall erosivity in subtropical catchments and implications for erosion and particle-bound contaminant transfer: a case-study of the Fukushima region. Hydrological and Earth Systems Science.

Land conservation research, 2005, Landuse map, http://nrbwww.mlit.go.jp/kokjo/inspect/landclassification/download/index.html (Last access May 2015) (in Japanese)

Lepage, H., Evrard, O., Onda, Y., Chartin, C., Lefevre, I., Sophie, A., Bonte, P., 2014a. Tracking the origin and dispersion of contaminated sediments transported by rivers draining the Fukushima radioactive contaminant plume, in: Sediment Dynamics from the Summit to the Sea, IAHS 367, 237243.

Lepage, H., Evrard, O., Onda, Y., Patin, J., Chartin, C., Lefèvre, I., Bonté, P., Ayrault, S., 2014b. Environmental mobility of ${ }^{110 \mathrm{~m}} \mathrm{Ag}$ : lessons learnt from Fukushima accident (Japan) and potential use for tracking the dispersion of contamination within coastal catchments. J. Environ. Radioact. 130, 4455 . 
Lepage, H., Evrard, O., Onda, Y., Lefèvre, I., Laceby, J.P., Ayrault, S., 2015. Depth distribution of cesium-137 in paddy fields across the Fukushima pollution plume in 2013. J. Environ. Radioact. 147, $157-164$.

Matsuzaka, Y., 1977. Major soil groups in Japan. Proc. Int. Semin. Soil Environ. Fertil. Manag. Intensive Agric. 89-95.

Ministry of Education, Culture, Sports, Science and Technology (MEXT), 2012, http://radioactivity.nsr.go.jp/ja/contents/7000/6289/24/203_0928.pdf (in Japanese).

Motha, J., Wallbrink, P., 2002. Tracer properties of eroded sediment and source material. Hydrol. Process. 16, 1983-2000.

National Institute for Agro-Environmental Sciences (NIAES), 1996. Classification of cultivated soils in Japan: third approximation, Classification Committee of Cultivated Soils.

Olley, J., Murray, A., 1993. Identifying sediment sources in a gullied catchment using natural and anthropogenic radioactivity. Water Resour. Res. 29, 1037-1043.

Olley, J., Brooks, A., Spencer, J., Pietsch, T., Borombovits, D., 2013a. Subsoil erosion dominates the supply of fine sediment to rivers draining into Princess Charlotte Bay, Australia. J. Environ. Radioact. 124, 121-129.

Olley, J., Burton, J., Smolders, K., Pantus, F., Pietsch, T., 2013b. The application of fallout radionuclides to determine the dominant erosion process in water supply catchments of subtropical South-east Queensland, Australia. Hydrol. Process. 27, 885-895.

Oracle (2013) Crystal Ball (Version: 11.2.3.500, 32 Bit, Classroom Edition)

Sawhney, B., 1972. Selective sorption and fixation of cations by clay minerals: a review. Clays Clay Miner. 20, 93-100.

Shozugawa, K., Nogawa, N. and Matsuo, M., 2012. Deposition of fission and activation products after the Fukushima Dai-ichi nuclear power plant accident. Environ. Pollut. 163, 243-247.

Tessier, L., Bonte, P., 2002. Suspended Sediment Transfer in Seine River Watershed, France: a Strategy Using Fingerprinting From Trace Elements, in: Science for Water Policy: The Implications of the Water Framework Directive, 79-99.

Wakahara, T., Onda, Y., Kato, H., Sakaguchi, A., Yoshimura, K., 2014. Radiocesium discharge from paddy fields with different initial scrapings for decontamination after the Fukushima Dai-ichi Nuclear Power Plant accident. Environ. Sci. Process. Impacts 16, 2580e2591.

Walling, D.E., Woodward, J.C., 1992. Use of radiometric fingerprints to derive information on suspended sediment sources, in: Erosion and Sediment Transport Monitoring Programmes in River Basin. IAHS Publication, Oslo, 153-164.

Wilkinson, S.N., Hancock, G.J., Bartley, R., Hawdon, A. a., Keen, R.J., 2013. Using sediment tracing to assess processes and spatial patterns of erosion in grazed rangelands, Burdekin River basin, Australia. Agric. Ecosyst. Environ. 180, 90-102.

Yamaguchi, M., Kitamura, A., Oda, Y., Onishi, Y., 2014. Predicting the long-term ${ }^{137}$ Cs distribution in Fukushima after the Fukushima Dai-ichi nuclear power plant accident: a parameter sensitivity analysis. J. Environ. Radioact. 135, 135-146. 
Yamamoto, T., 2013. Quantitative re-description of tephra units since $0.3 \mathrm{Ma}$ in the Tochigi-Ibaraki region, NE Japan. Bull. Geol. Surv. JAPAN 64, 251-304.

Yamashiki, Y., Onda, Y., Smith, H.G., Blake, W.H., Wakahara, T., Igarashi, Y., Matsuura, Y., Yoshimura, K., 2014. Initial flux of sediment-associated radiocesium to the ocean from the largest river impacted by Fukushima Daiichi Nuclear Power Plant. Sci. Rep. 4, 3714.

Yasutaka, T., Naito, W., 2015. Assessing cost and effectiveness of radiation decontamination in Fukushima Prefecture, Japan. J. Environ. Radioact. 1-9.

Yoshikawa, N., Obara, H., Ogasa, M., Miyazu, S., Harada, N., Nonaka, M., $2014 .{ }^{137}$ Cs in irrigation water and its effect on paddy fields in Japan after the Fukushima nuclear accident. Sci. Total Environ. 481, 252-259.

Yoshimura, K., Onda, Y., Kato, H., 2015. Evaluation of radiocaesium wash-off by soil erosion from various land uses using USLE plots. J. Environ. Radioact. 139, 362-9. 
1

\section{Acknowledgements}

This work has been supported by the French National Research Agency (ANR) in the framework of AMORAD project (ANR-11-RSNR-0002). Hugo Lepage received a PhD fellowship from CEA (Commissariat à l'Energie Atomique et aux Energies Alternatives). 


\section{Figure captions}

Figure 1 - Elevation map of the investigated catchments within Fukushima Prefecture in Northern Japan (Geospatial Information Authority of Japan, 2015). Location of the main dams and the continuous rainfall monitoring station (Japanese Meteorological Agency, 2014). Initial radiocesium contamination contour lines were derived from Chartin et al. (2013).

Figure 2 - Rainfall depths (monitored in the Niida catchment) (Japan Meteorological Agency, 2014) with occurrence of major typhoons during the study period and timing of the six sampling campaigns.

Figure 3 - Source and sediment samples (including MEXT samples - MEXT, 2011) collected and used in the ${ }^{137} \mathrm{Cs}$ distribution modelling, and initial radiocesium contamination of the investigated catchments (Chartin et al., 2013).

Figure 4 - Soil map (Economic Planning Agency 1972) and location of the source and sediment samples collected in the investigated catchments and used in the distribution modelling based on the soil type.

Figure 5 - Figure $5-{ }^{137} \mathrm{Cs}$ distribution of the median and the MAD for the sources (coastal plains and upstream) in the two catchments studied and rank plots of ${ }^{137} \mathrm{Cs}$ activities measured by gamma-spectrometry. ${ }^{137} \in s$ distribution of the median and the MAD for the sources (coastal plains and upstream) in the two catchments studied and rank plots.

Figure 6 - Contribution of each source (upstream and coastal plain area) to coastal plain sediments collected in both catchments.

Figure 7- Scatter plot of the mean and standard deviation of Sc and $\mathrm{Yb}$ concentrations in each source (Andosol, Cambisol and Fluvisol).

Figure 8 - Contribution of each source to the groupings of sediments transiting the rivers in the upstream and coastal plain areas of both catchments. 


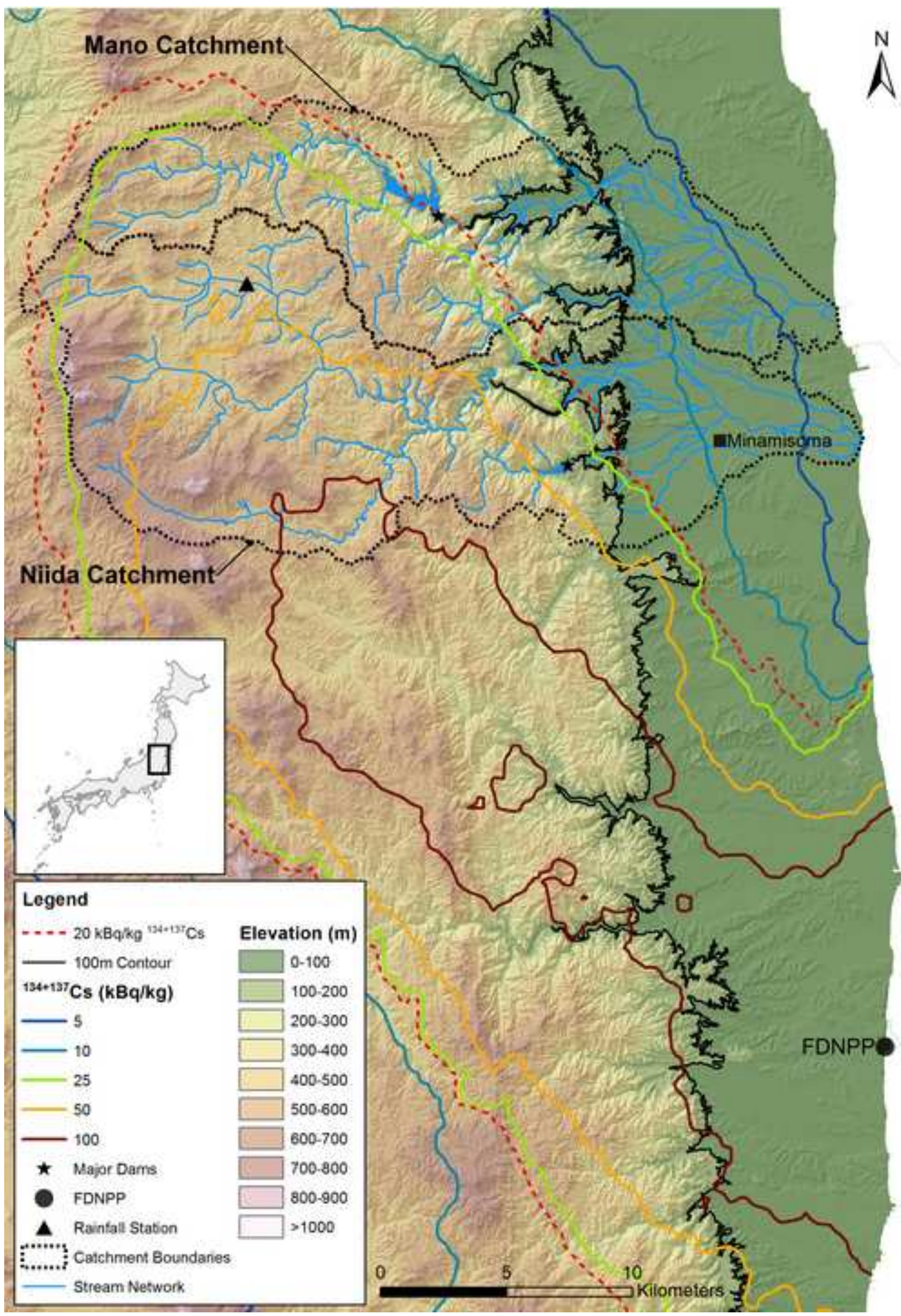




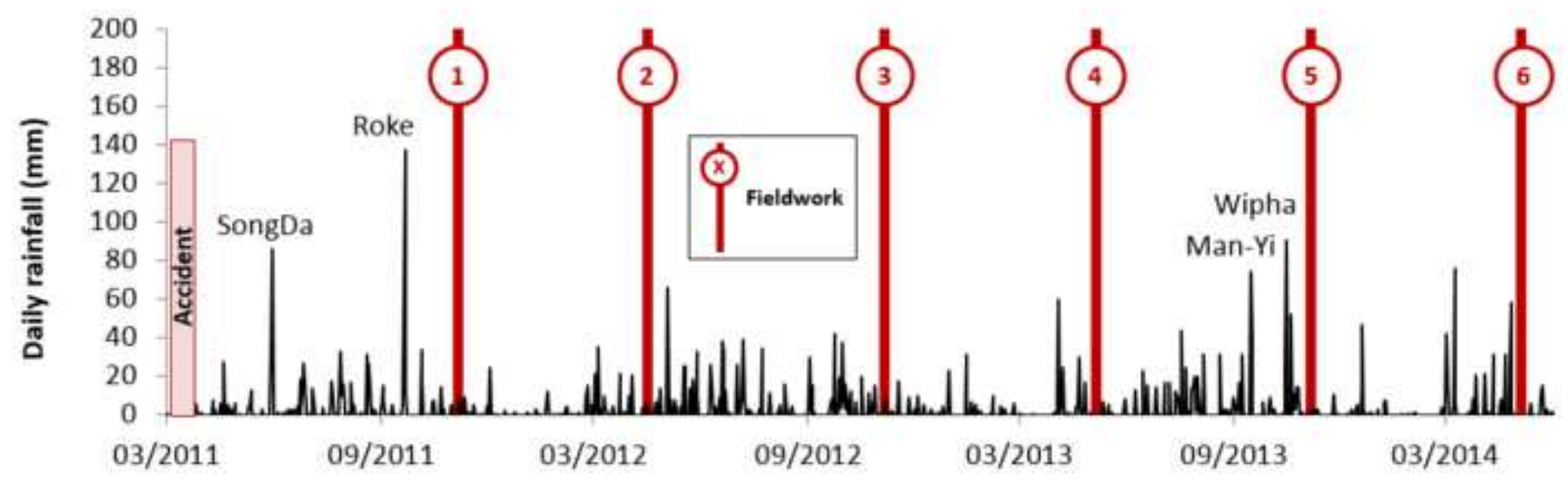




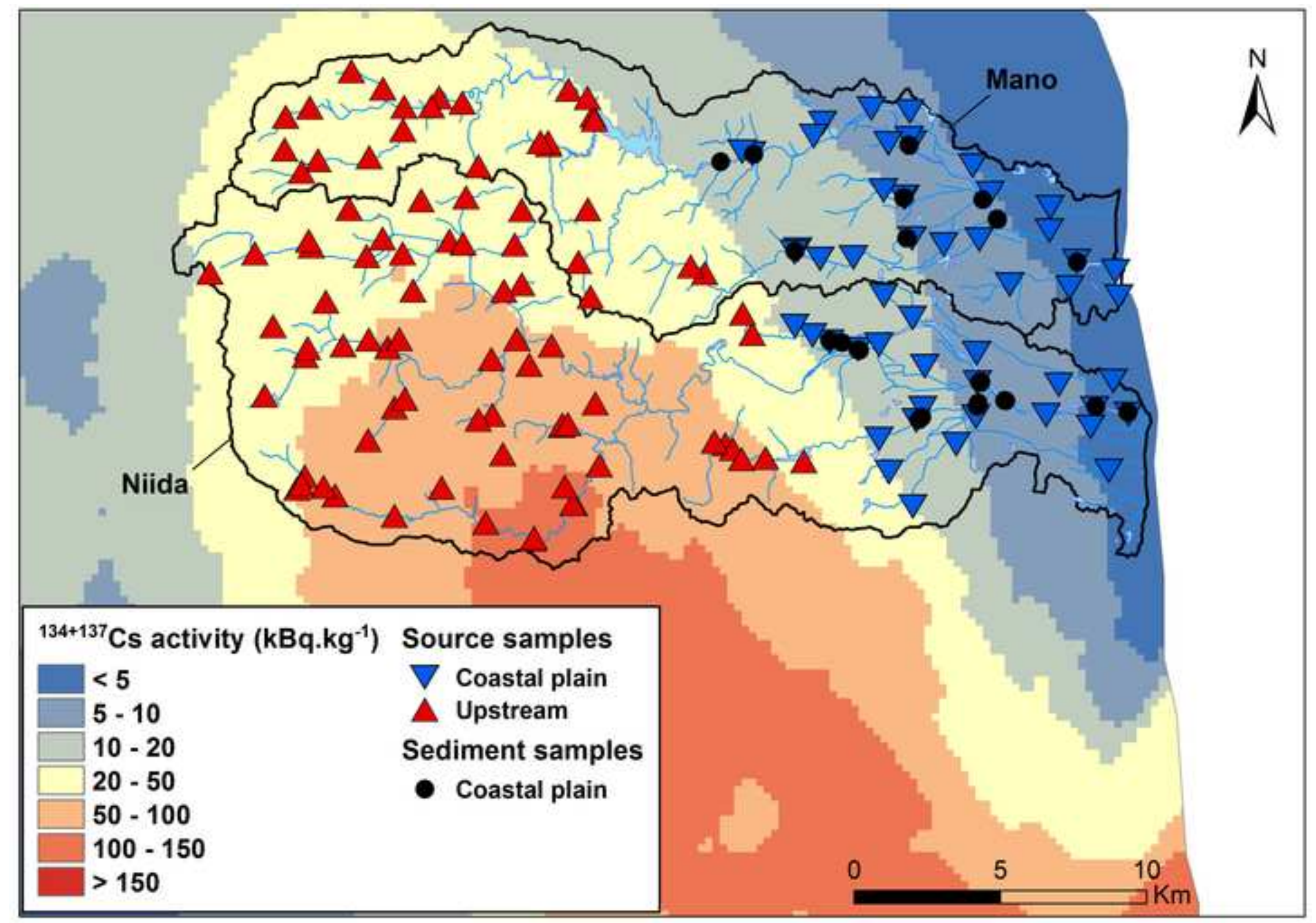




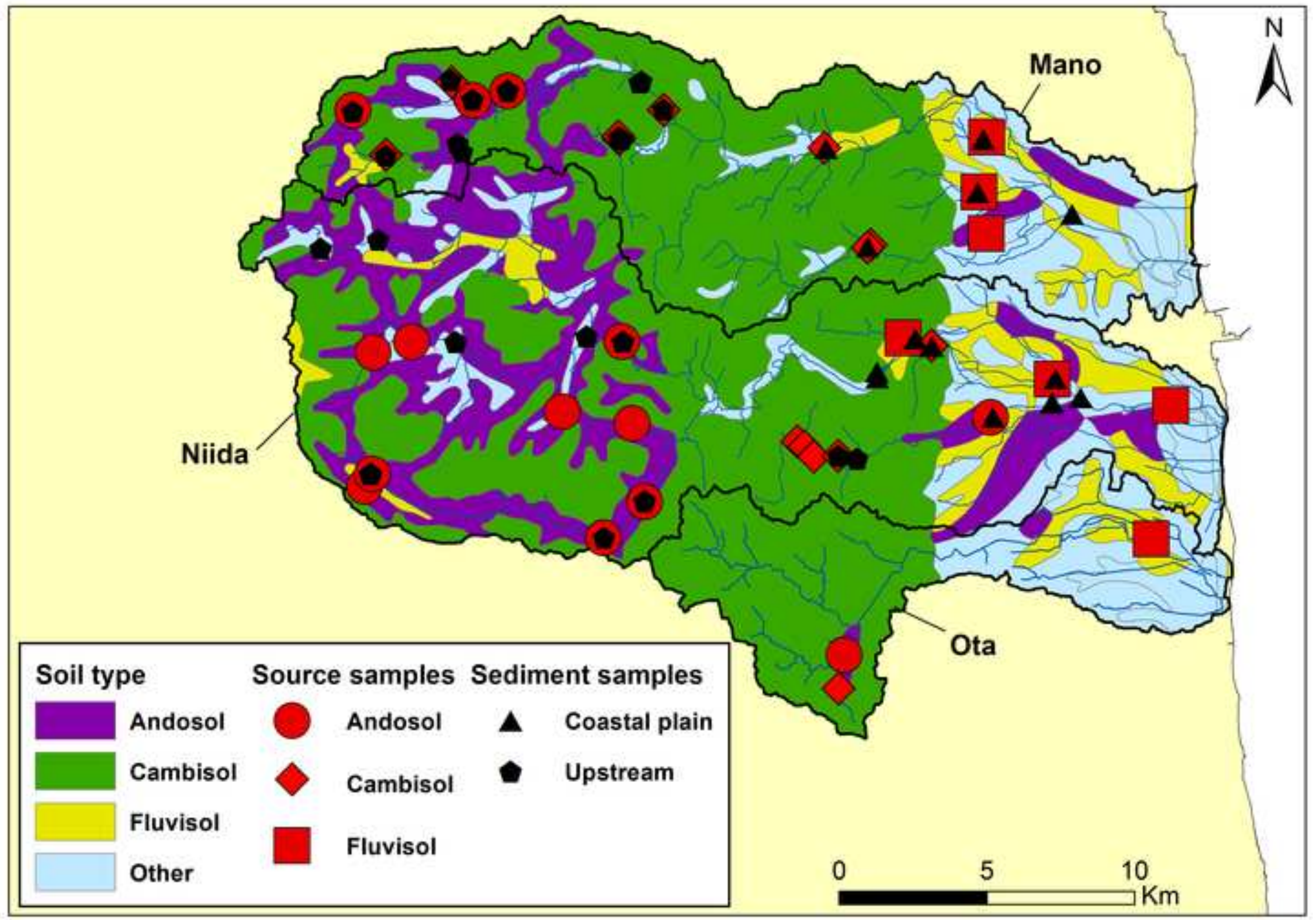


Mano

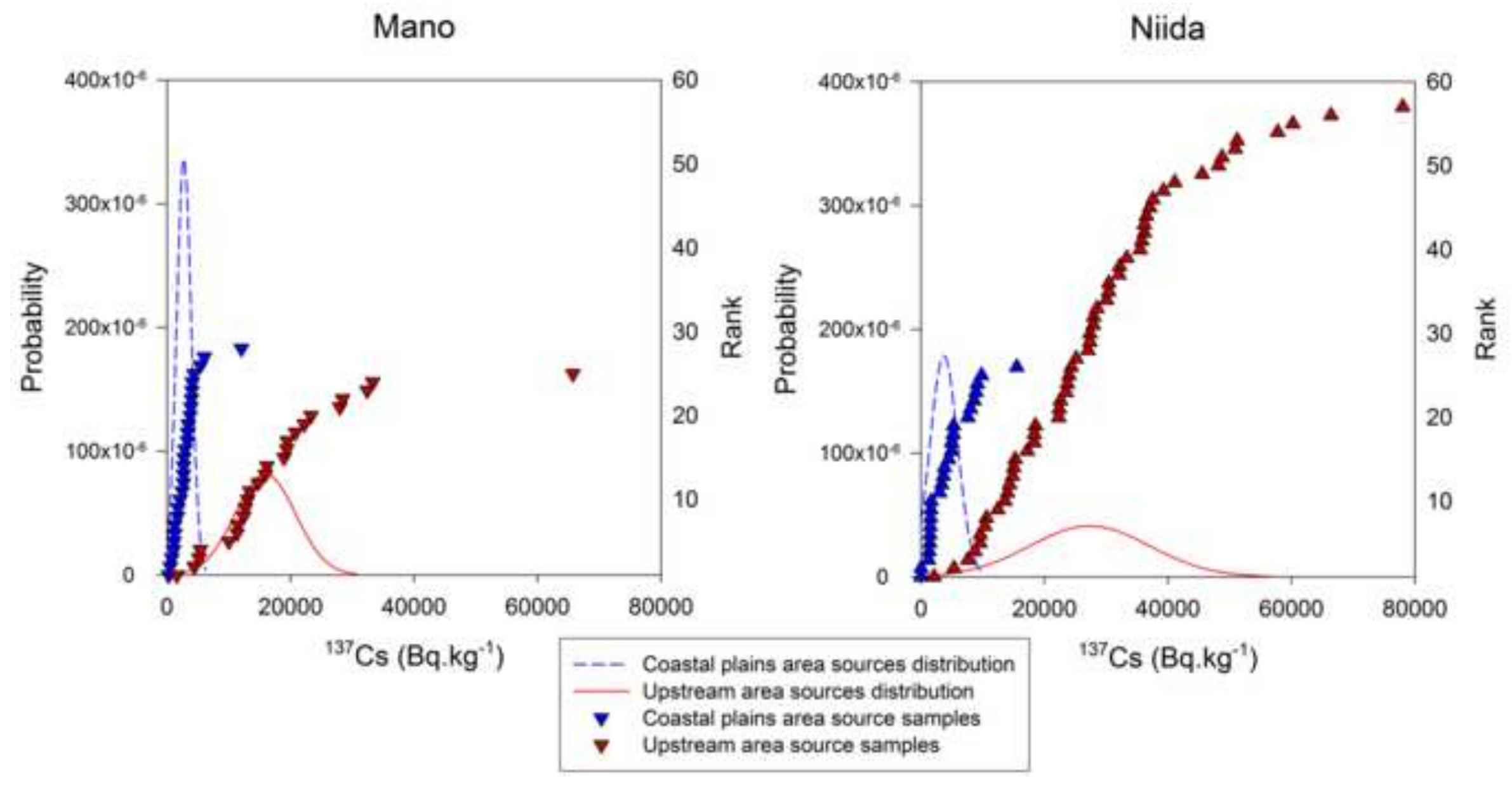

Niida 


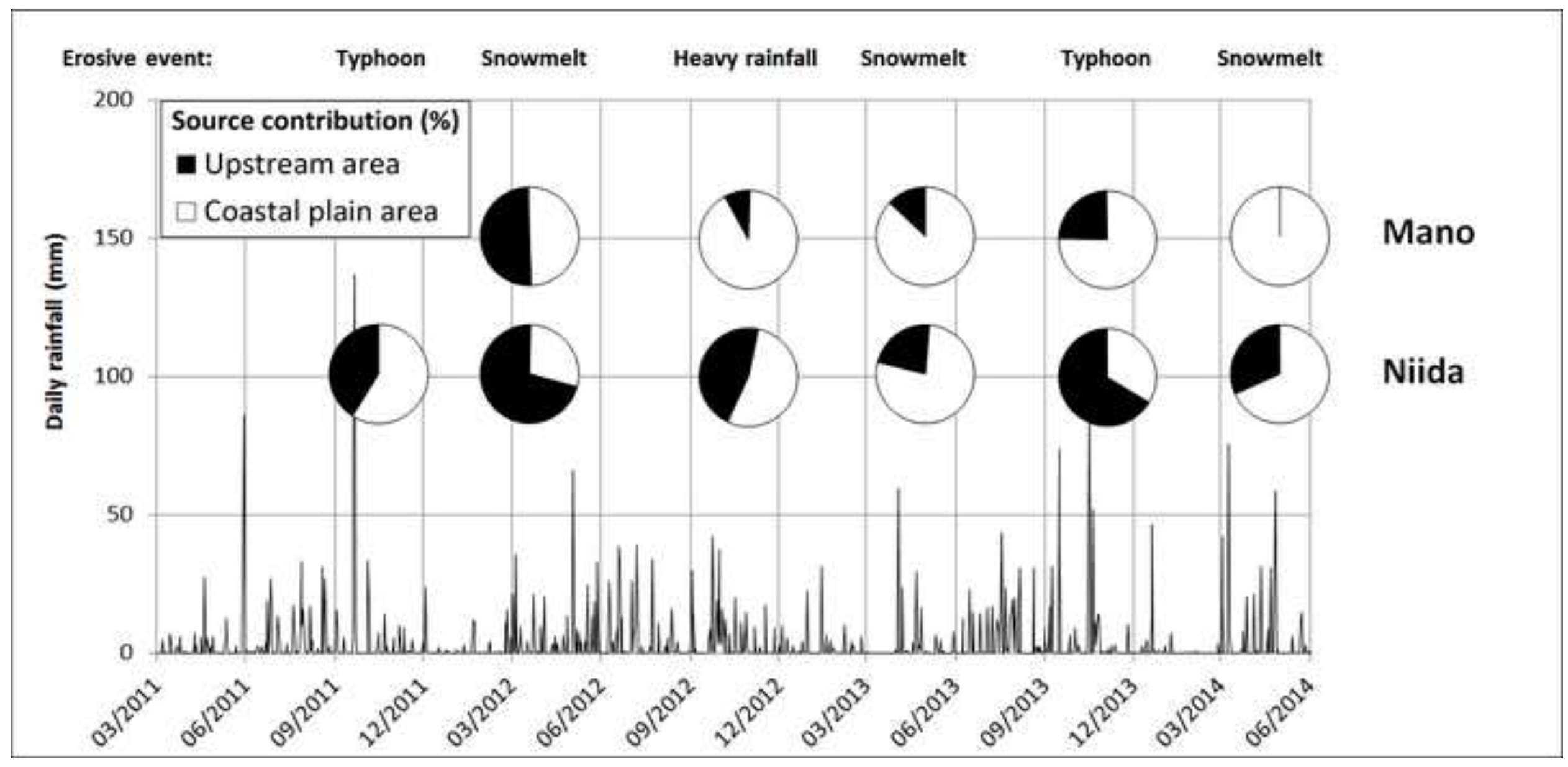




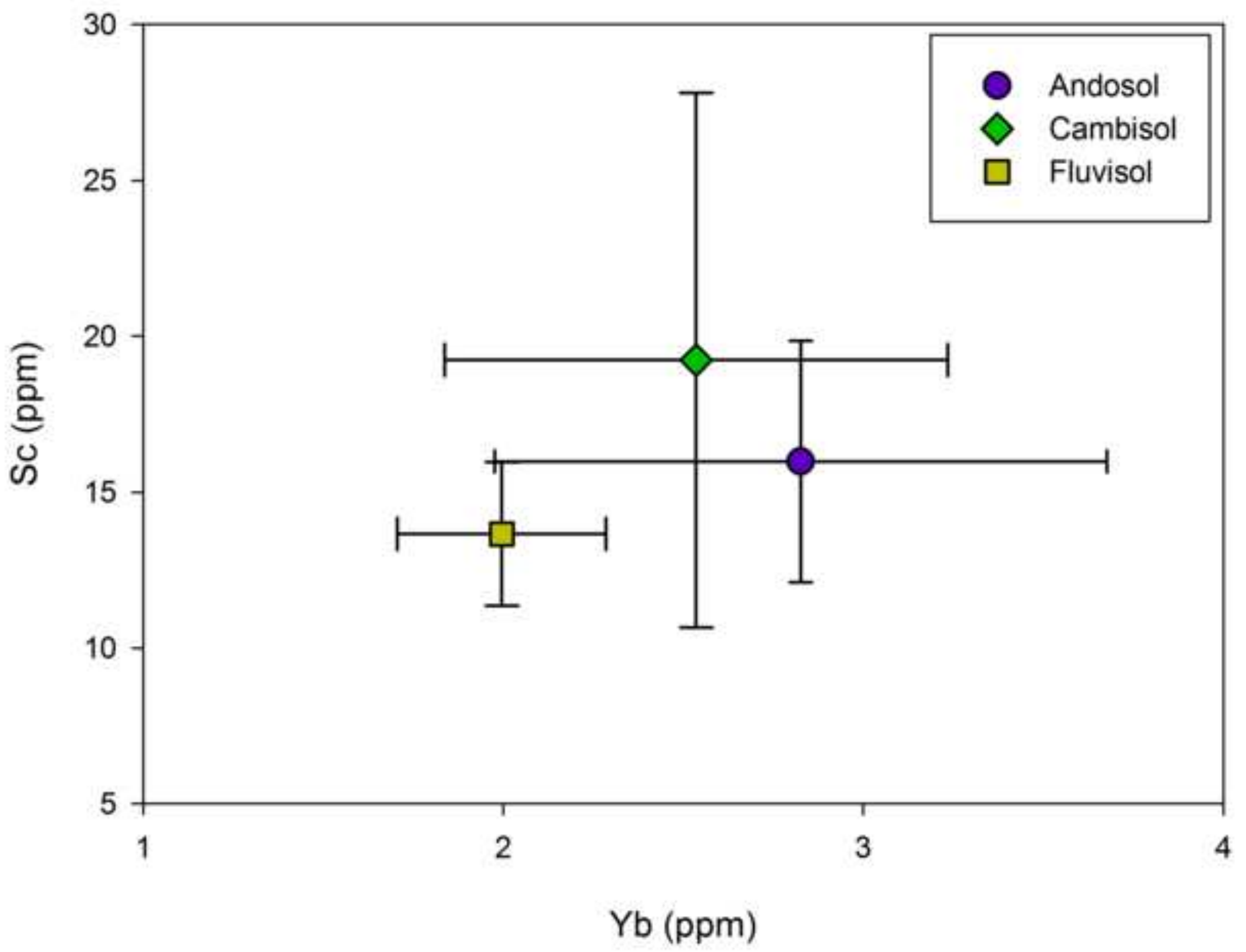



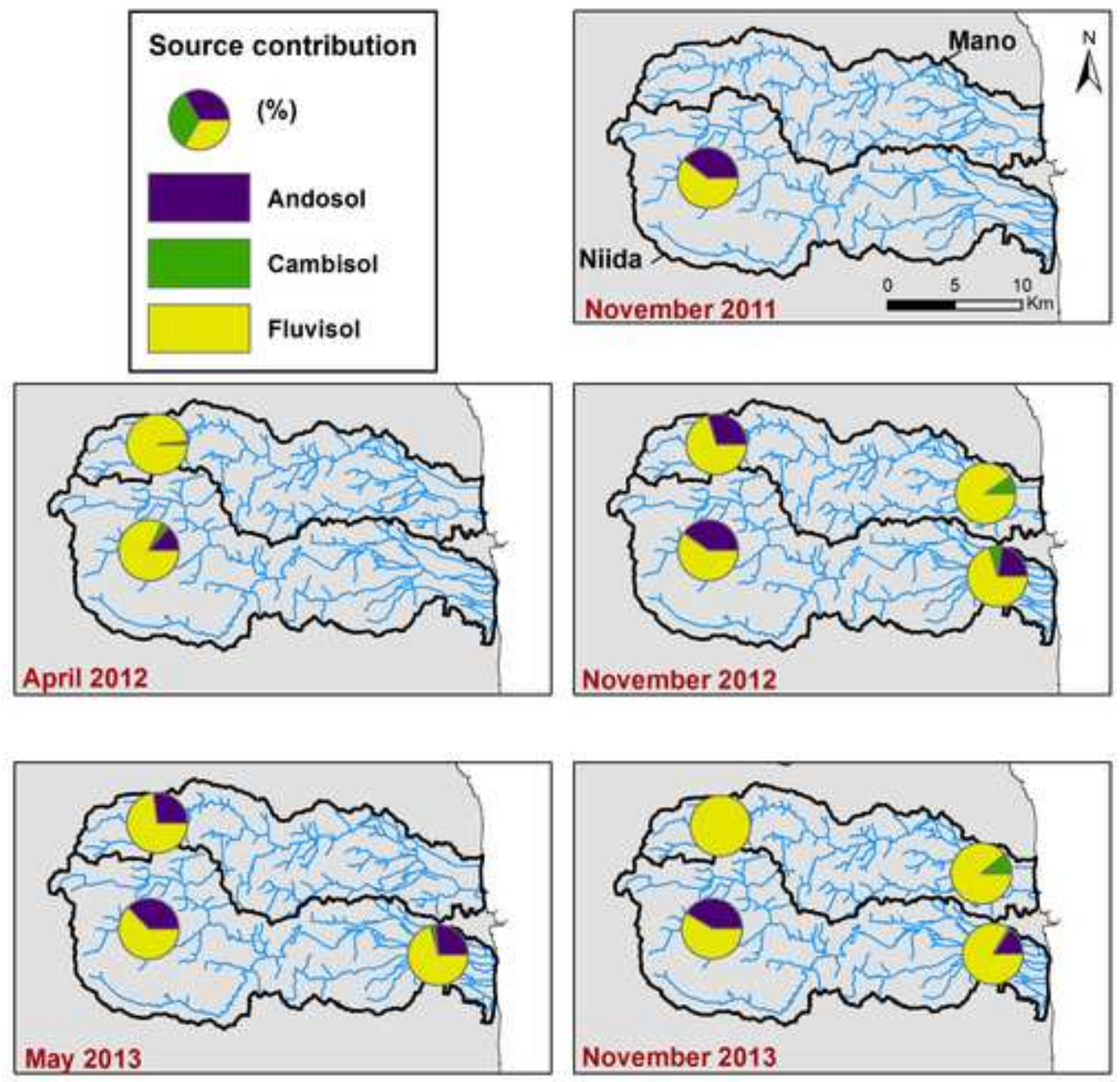
Table 1 - Mean and median of ${ }^{137}$ Cs activities $\left(\mathrm{Bq} \cdot \mathrm{kg}^{-1}\right)$ in the catchments.

\begin{tabular}{|c|c|c|c|c|c|c|c|}
\hline Catchment & $\begin{array}{c}\text { Catchment } \\
\text { area }\end{array}$ & $\begin{array}{c}\text { Mean of } \\
{ }^{137} \text { Cs } \\
\text { activities }\end{array}$ & $\begin{array}{c}\text { Standard } \\
\text { deviation }\end{array}$ & $\begin{array}{c}\text { Coefficient } \\
\text { of } \\
\text { variation } \\
(\%)\end{array}$ & $\begin{array}{c}\text { Median } \\
\text { of }{ }^{137} \text { Cs } \\
\text { activities }\end{array}$ & $\begin{array}{c}\text { Median } \\
\text { absolute } \\
\text { deviation }\end{array}$ & $\begin{array}{c}\text { Relative } \\
\text { median } \\
\text { absolute } \\
\text { deviation } \\
\text { d\%) }\end{array}$ \\
\hline Niida & Coastal plain & 4560 & 3738 & 82 & 3730 & 2231 & 60 \\
\hline & Upstream & 28444 & 15886 & 56 & 27347 & 9719 & 36 \\
\hline Mano & Coastal plain & 3056 & 2277 & 74 & 2721 & 1187 & 44 \\
\hline
\end{tabular}


Table 2 - Contribution of upstream and coastal plain areas to sediments transiting the coastal plains of the catchments.

\begin{tabular}{|c|c|c|c|}
\hline Catchment & Campaign & $\begin{array}{c}\text { Contribution of the } \\
\text { upstream area }\end{array}$ & SD \\
\hline \multirow{5}{*}{ Mano } & April 2012 & $50 \%$ & $11 \%$ \\
\hline & November 2012 & $9 \%$ & $12 \%$ \\
\hline & May 2013 & $13 \%$ & $12 \%$ \\
\hline & November 2013 & $24 \%$ & $12 \%$ \\
\hline & May 2014 & $0 \%$ & $15 \%$ \\
\hline \multirow{6}{*}{ Niida } & November 2011 & $41 \%$ & $12 \%$ \\
\hline & April 2012 & $71 \%$ & $11 \%$ \\
\hline & November 2012 & $46 \%$ & $13 \%$ \\
\hline & May 2013 & $22 \%$ & $13 \%$ \\
\hline & November 2013 & $66 \%$ & $10 \%$ \\
\hline & May 2014 & $32 \%$ & $15 \%$ \\
\hline
\end{tabular}


Table 3 - Results of the Kruskal-Wallis test to determine the discriminant elements when using the mean and the standard deviation of each element for each source.

\begin{tabular}{|c|c|}
\hline Element & Kruskal-Wallis $\mathrm{p}$-value \\
\hline $\mathrm{Ce}$ & 0.10 \\
\hline $\mathrm{Co}$ & 0.92 \\
\hline $\mathrm{Cs}$ & 0.31 \\
\hline $\mathrm{Fe}$ & 0.07 \\
\hline $\mathrm{Hf}$ & 0.01 \\
\hline $\mathrm{La}$ & 0.24 \\
\hline $\mathrm{Na}$ & Not conservative \\
\hline $\mathrm{Sc}$ & 0.01 \\
\hline $\mathrm{Sm}$ & 0.06 \\
\hline $\mathrm{Th}$ & 0.97 \\
\hline $\mathrm{Yb}$ & 0.03 \\
\hline $\mathrm{Zn}$ & Not conservative \\
\hline
\end{tabular}


Table 4 - Distribution modelling results for the three-source model for the grouped sediments.

\begin{tabular}{|c|c|c|c|c|c|c|c|c|}
\hline $\begin{array}{l}\text { Catch } \\
\text { ment }\end{array}$ & Campaign & Area & $\begin{array}{c}\text { Andosol } \\
\text { contribution (\%) }\end{array}$ & $\begin{array}{c}\mathrm{MU}^{*} \\
(\%)\end{array}$ & $\begin{array}{c}\text { Cambisol } \\
\text { contribution (\%) } \\
\end{array}$ & $\begin{array}{c}\mathrm{MU}^{*} \\
(\%) \\
\end{array}$ & $\begin{array}{c}\text { Fluvisol } \\
\text { contribution (\%) } \\
\end{array}$ & $\begin{array}{c}U^{*} \\
(\%) \\
\end{array}$ \\
\hline Mano & $\begin{array}{c}\text { November } \\
2012\end{array}$ & $\begin{array}{l}\text { Coastal } \\
\text { plain }\end{array}$ & 1 & 5 & 9 & 6 & 90 & 8 \\
\hline Mano & $\begin{array}{c}\text { November } \\
2013\end{array}$ & $\begin{array}{c}\text { Coastal } \\
\text { plain }\end{array}$ & 1 & 7 & 11 & 9 & 88 & 11 \\
\hline Mano & April 2012 & $\begin{array}{c}\text { Upstrea } \\
\mathrm{m}\end{array}$ & 0 & 13 & 2 & 20 & 98 & 13 \\
\hline Mano & $\begin{array}{c}\text { November } \\
2012\end{array}$ & $\begin{array}{c}\text { Upstrea } \\
\mathrm{m}\end{array}$ & 30 & 12 & 0 & 12 & 70 & 13 \\
\hline Mano & May 2013 & $\begin{array}{c}\text { Upstrea } \\
\mathrm{m}\end{array}$ & 27 & 11 & 0 & 11 & 73 & 15 \\
\hline Mano & $\begin{array}{c}\text { November } \\
2013\end{array}$ & $\begin{array}{c}\text { Upstrea } \\
\mathrm{m}\end{array}$ & 0 & 6 & 0 & 5 & 100 & 17 \\
\hline Niida & $\begin{array}{c}\text { November } \\
2012\end{array}$ & $\begin{array}{c}\text { Coastal } \\
\text { plain }\end{array}$ & 22 & 13 & 7 & 7 & 71 & 13 \\
\hline Niida & May 2013 & $\begin{array}{c}\text { Coastal } \\
\text { plain }\end{array}$ & 27 & 14 & 3 & 8 & 71 & 15 \\
\hline Niida & $\begin{array}{c}\text { November } \\
2013\end{array}$ & $\begin{array}{c}\text { Coastal } \\
\text { plain }\end{array}$ & 15 & 8 & 1 & 7 & 83 & 10 \\
\hline Niida & $\begin{array}{c}\text { November } \\
2011\end{array}$ & $\begin{array}{c}\text { Upstrea } \\
\mathrm{m}\end{array}$ & 40 & 10 & 0 & 6 & 60 & 10 \\
\hline Niida & April 2012 & $\begin{array}{c}\text { Upstrea } \\
\mathrm{m}\end{array}$ & 14 & 8 & 4 & 7 & 82 & 10 \\
\hline Niida & $\begin{array}{c}\text { November } \\
2012\end{array}$ & $\begin{array}{c}\text { Upstrea } \\
\mathrm{m}\end{array}$ & 40 & 14 & 0 & 20 & 60 & 14 \\
\hline Niida & May 2013 & $\begin{array}{c}\text { Upstrea } \\
\mathrm{m}\end{array}$ & 37 & 18 & 0 & 9 & 63 & 16 \\
\hline Niida & $\begin{array}{c}\text { November } \\
2013\end{array}$ & $\begin{array}{c}\text { Upstrea } \\
\mathrm{m}\end{array}$ & 41 & 17 & 0 & 15 & 59 & 16 \\
\hline
\end{tabular}

*MU = Modelled Uncertainty 

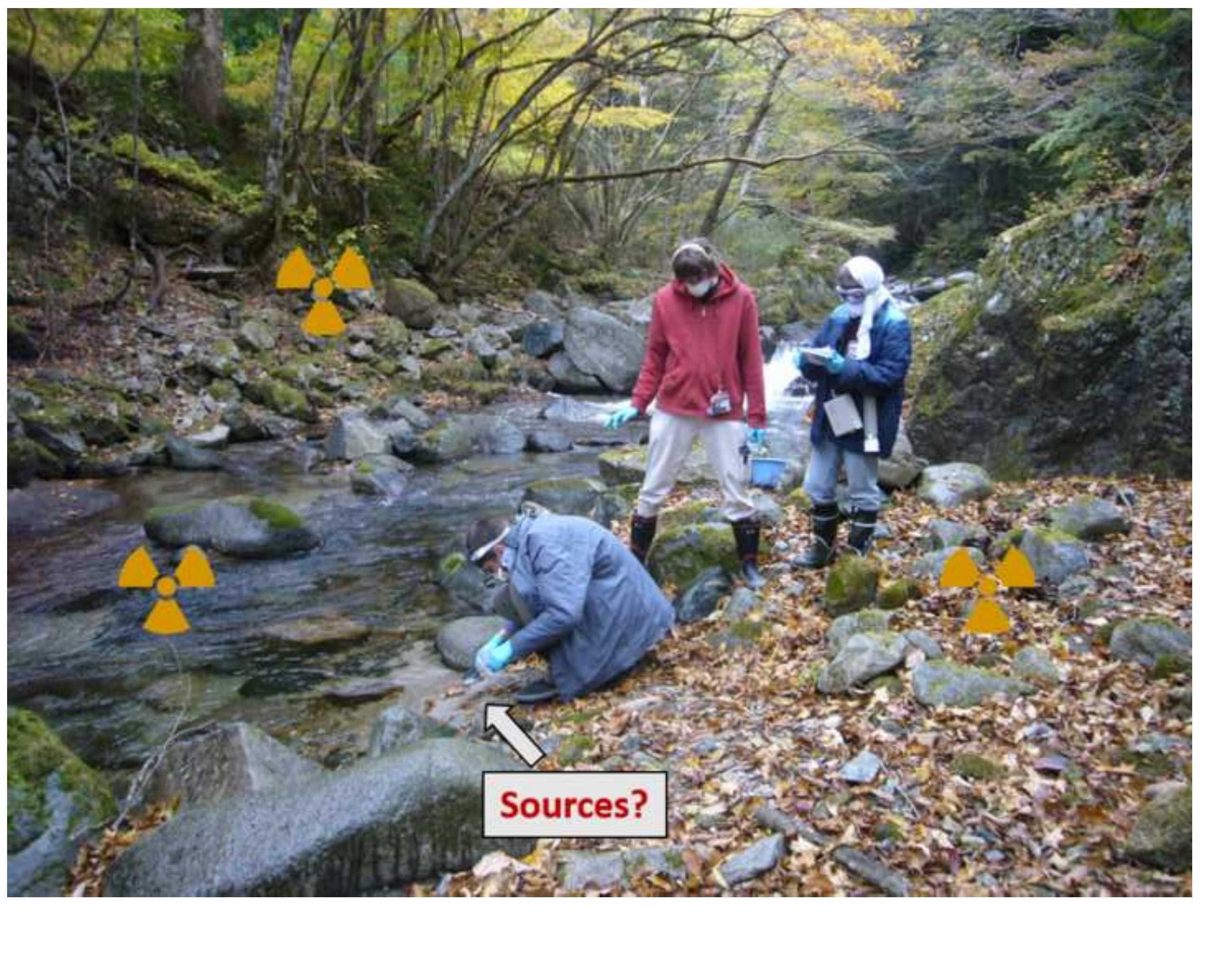

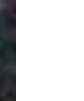

